\title{
Learning Practices Learning Based Approach M-Apos to Improve Communication Capability Mathematic Participants Grade VII of Junior High School
}

\author{
$1^{\text {st Basman Abdullah }}$ \\ Mathematics and Science Faculty \\ Universitas Negeri Padang \\ Padang, Indonesia \\ basmanabdullah1@gmail.com
}

\author{
$2^{\text {nd }}$ Yerizon \\ Educational Science Faculty \\ Universitas Negeri Padang \\ Padang, Indonesia
}

\author{
$3^{\text {rd }}$ Armiati \\ Mathematics and Science Faculty \\ Universitas Negeri Padang \\ Padang, Indonesia
}

\begin{abstract}
The ability of mathematical communication is the ability that must be possessed by learners in math. At present the mathematical communication skills in Indonesia are still relatively low, this is evidenced by several studies that have been carried out for students' mathematical communication skills. In this study, mathematical communication skills were improved through learning tools with the M-APOS approach with mind mapping assisted with products produced in the form of RPP and LKPD that could be used to teach material in the second semester of grade VII of Junior High School curriculum 2013. The purpose of this study is to produce practical learning tools for use in the classroom learning. The development model used in this research is a Plomp model consisting of 3 phases, ie preliminary analysis phase, development phase or prototype making, and assessment phase. However, the focus of this research is the assessment phase, which is based on teacher questionnaire, student's questionnaire and observation sheet by the researcher and one of the other mathematics teachers on the learning done by the math teacher. Aspects assessed at the practical stage are aspects of attractiveness, process of use, ease of use, time and equivalence. The results showed that the learning device with the M-APOS approach assisted by mind mapping was practically used in the learning process in the classroom. Based on the calculation of the value of practicality including high category.
\end{abstract}

Keywords: Learning Device, M-APOS, Mind Mapping, Practicality

\section{INTRODUCTION}

Learning resources are a very important factor in determining the success of the learning process. In general, learning resources used by teachers have not provided work steps that help learners discover and construct their own concepts from learning materials. This results in students feeling lazy to find and construct their own concepts from learning materials. Mistakes made by students are mistakes in building a mathematical model of a problem [18]. This resulted in learners feel lazy to read books and LKPD grip owned, so that learners tend to receive information from teachers only. The instructional materials that are prepared should have the principles of relevance, consistency and adequacy, so that they still provide space for students to develop their reasoning [6]. So the information received should encourage learners to develop thinking skills in processing problems encountered based on daily life. Contextual learning in mathematics is to get the ability to think, reason, communicate, prove and solve problems [20].

Looking at the above problems, a new breakthrough is needed that demands the ability of the teacher to be able to create a learning resource that is able to motivate students' positive attitudes towards mathematics learning and encourage students to identify their own learning material without having to rely on the teacher's explanation. In addition, teachers should be able to create a learning environment centered on learners that can improve students' mathematical communication skills in writing with learning from the daily environment is more real, so that learning is more meaningful for learners. Indirectly, teachers can design interesting learning, invite students to think systematically in solving mathematical problems and able to improve students' mathematical communication skills in writing. The application of a scientific approach to learning involves the process of observing, questioning, reasoning, trying and communicating [17]. The solution that is expected to be used is a learning tool based on the M-APOS approach with mind mapping assistance.

Learning device with M-APOS approach with mind mapping is a tool developed by the principles and components of M-APOS approach (action, process, object and schema), for the activities in schema developed by mind mapping. In general, the assessment of the practicability of learning tools can be seen from several aspects such as attractiveness aspect, usage process aspect, ease of use aspect, time aspect and equivalence aspect.

\section{METHODS}

This research is a development research with development plan of Plomp model. Researchers use this model because it is more systematic, directed, analytic, and suitable for developing learning tools. The Plomp model 
consists of 3 stages, namely the initial investigation phase (preliminary research), the development or prototype phase (development or prototyping phase), and the assessment phase [12]. The practical phase is at the stage of developing or making prototypes and in the assessment phase. Practicality was assessed by questionnaire responses from learners, teacher response questionnaire and observation results of instructional devices observed by the researcher and one of the mathematics teachers on the use of learning tools developed by mathematics teachers teaching in grade VII.

\section{RESULT AND DISCUSSION}

\section{Mathematical Communication Skills Learners}

In the context of learning, communication is an important means for a teacher in conducting a learning process where the teacher will build understanding of learners about the material to be taught. Through teacher communication as a source of convey information to the recipient (learners) by using symbols either oral, written, non verbal language. Instead, learners will convey various messages as a response to the teacher resulting in two-way communication in order to improve communication success to achieve learning objectives. Students' ability to express ideas, answers and problem solving is still low [10].

Mathematical learning also requires communication ie mathematical communication. Mathematical communication according to the Ministry of Religion is "the ability to express and interpret mathematical ideas verbally, in writing, tables or graphs" [1]. Furthermore, according to the National Center for Teaching Mathematics (NCTM), expressing mathematical communication is a communication in which mathematical ideas are exploited in various perspectives, helping to sharpen students' way of thinking and sharpen the ability of students to see various mathematical material linkages., tools help "measure" the growth of understanding, and reflect students' mathematical understanding, students can organize and condition their mathematical thinking, communication between students in learning mathematics is very important for: constructing mathematical knowledge, developing problem solving, and increasing reasoning, growing confidence, and increasing social skills,"Writing and talking" can be a very powerful tool to form an inclusive mathematical community [1]. Education is one manifestation of human culture that is dynamic and full development [9]. Communication that occurs in mathematics can occur in the real world, the abstract structure of a system, and mathematics itself is a form of communication used for the development of mathematics [11]. NCTM is related to the development of mathematical communication ability, there are some benefits obtained by the students that is modeling the situation with oral, written, drawing, graphic, and algebraically, reflecting and clarifying in thinking about matemetika ideas in various situations, developed an understanding of mathematical ideas including the role of definitions in mathematics, using reading, listening and writing skills to interpret and evaluate mathematical ideas, reviewing mathematical ideas through conjecture and convincing reasons, understanding the value of mathematical notation and role in the development of mathematical ideas [1].

Baroody there are at least two important reasons that make communication in learning mathematics need to be the focus of attention, namely mathematics as language, mathematics not only as a tool for thinking, solving problems, tools for finding patterns, or solving problems but also mathematics "an invaluable tool for communicating a variety of ideas clearly, precisely and succinetly. mathematics learning as social activity, as a social activity in the learning of mathematics, the interaction between learners as well as the communication of teachers and learners is an important part for "nurturing children's mathematical potential" [1].

The role of mathematical communication in learning mathematics expressed by Greenes and Schulman, is the central strength for learners in formulating mathematical concepts and strategies, the success capital for learners of the approach and completion in the exploration and investment of mathematics, container for learners in communicating with their friends to obtain information, sharing thoughts and meetings, brainstorming, assessing and sharpening ideas to convince others [1]. Assessment of mathematical communication ability of learners that can be measured based on indicators of mathematical communication ability of learners. (Utari, 2014) is to state situations, pictures, diagrams, or real objects into languages, symbols, ideas, or mathematical models; explaining ideas, situations, and mathematical relations both orally and in writing; listening, discussing, and writing about mathematics; reading with the understanding of a written mathematical representation; reveals a description or a mathematical paragraph in its own language [14]. Students have low mathematical abilities because they are used to learning to hear the teacher's explanation [19].

Based on the above, M-APOS approach can improve students' mathematical communication ability. This can be seen from the components of the M-APOS approach developed, with the learning using M-APOS approach assisted mind mapping this learner can train himself in accordance with the indicators contained in the mathematical communication skills. Indirectly, the $\mathrm{M}$ APOS approach assisted by mind mapping can be used as a means to convey or understand the concept or learning material [13]. Each component of the M-APOS approach assisted by mind mapping is presented to encourage students to communicate mathematically in expressing the concepts they find and understand.

\section{The M-APOS approach is assisted by mind maps}

The M-APOS approach is one of the alternatives that can be used to improve the ability of mathematical communication. APOS theory is a constructivist theory of how the possibility of the achievement or learning of a mathematical concept or principle. The APOS theory (Dubinsky \& McDonald, 2001) suggests that each individual must have the proper mental structure to understand the mathematical concepts. Mental structure refers to the possible actions, processes, objects and 
schemes needed to learn the concept. The components of the M-APOS approach are action, process, object and schema. APOS theory assumes that the mathematical knowledge possessed by a person is the result of interaction with others and the results of the person's mental constructions in understanding mathematical ideas. These mental constructions are action, process, object and schema. Action Stage will help learners to improve linking real objects, images, diagrams and tebel in mathematical ideas based on the stimulus provided from the external learners. Objects help in increasing the use of ideas, situations and expressing solutions to problems. Process improves in stating the events or problems put forward in language or mathematical symbols. Schema improves in the workings of the brain processing information, storing information, conveying information, connecting between materials and reminding learners about what they have learned. The M-APOS approach is a modification of the APOS approach that not only uses computers, but can be other learning resources, such as LKPD, textbooks and so on. The authors feel the need to modify the theory of APOS because the facilities and computer infrastructure at school is not sufficient to make learning APOS by using computers. The all mathematical conceptions can be understood as actions, processes, objects or schemes [2]. Based on the theory of APOS and the learning and teaching hypothesis is a recurring cycle consisting of three components of ADL or ACE: (A) activity, (C) class discussion, and (E) the exercise is done outside the classroom [3].

APOS theory helps learners to construct their own knowledge. Students will not accept a mathematical concept in the finished form. The role of teachers in learning is not the ultimate answer to the questions of the students or teachers giving materials, examples and giving exercises, but rather directing learners to construct mathematical knowledge to obtain the correct mathematical structure. In order for mathematical knowledge and structure to be achieved, learners must shape it into their own experiences, to shape students' experiences, teachers play a role in directing them and providing assistance, so that the mastery of constructed concepts becomes stronger. The APOS theory compares how far students form their mental construction of a mathematical concept. Activity on each of the components of APOS can be a solution to train the indicators of mathematical communication ability in the students, that's why the solution chosen is the learning with the M-APOS approach.

Schema formation in the learners themselves can be done through activities to create a mind map (mind mapping) in the learning process. The mind map is how the brain processes information. The information is communicated. The ability of learners to connect the materials that exist to each other and improve the formation of schemes in the learner's brain and remind again what students have learned, activate the whole brain, grouping concepts, divert information from short-term memory to long-term memory. The right strategy to train students is to use mind mapping. Mind mapping is a learning strategy that emphasizes the research process and records what is thought by combining text and images visualized in the form of maps. This strategy will help learners to store information in the cognitive structure of the brain so as to make the information more durable in memory. Mind mapping makes learning more enjoyable because the imagination and creativity of note-takers is not limited, enhances understanding, is flexible because it can add ideas points in a suitable place and focus on ideas not anymore words. Increase students 'mastery of learning material and improve students' mathematical communication skills in absorbing information from everyday life into mathematical language with the mind maps of their students.

Mind maps are the whole brain utilization technique by using visual images and other graphical infrastructure to form an impression [4]. Mind mapping is the easiest way to enter information into the brain and to extract information from the brain [15]. Based on the above opinion, it is concluded that mind map helps learners to utilize the brain optimally so that information last long in memory. The use of color, movement, image, contrast, organizational decisions, information encoded in our mental maps [8]. Michael Michalco states that mind maps will help activate the whole brain, clear the mind from mental tangling, enable us to focus on language, help show relationships between sections of mutually exclusive information, give a clear picture on overall and details, enabling us to group concepts, help us to awaken them, requires us to focus on subjects that help divert information from short-term memory to longterm memory [16]. Then, as for the benefits of learning using mind maps is it's flexible because whenever you can add information, your attention becomes focused because you concentrate on big ideas, and still don't forget the small details, your understanding increases and gives you great notes to study, and fun [5].

\section{Product Practices Developed}

The practicality of the product developed is the use of learning devices with the M-APOS approach assisted by mind mapping, which is RPP and LKPD. Practical data of multimedia learning by users, namely teachers and students, is obtained through teacher response questionnaires, student response questionnaires, and observation sheets filled by researchers and one of the mathematics teachers according to the conditions when the learning was carried out by the teacher. Based on observation data and filling in questionnaires by teachers, then performed data analysis by looking for value to see the level of product practicability developed. From the results of the calculation, the calculation results obtained for the teacher response questionnaire were 3.62 with a percentage of $91 \%$ and included a high practicality category. This shows that the learning device with the M-APOS approach is mind-aided practical mapping to be used by teachers as teaching staff who will use these learning tools to teach mathematical concepts and improve mathematical communication skills of students in class VII of SMP / MTs semester II 2013 curriculum. The following is the result of processing the teacher's response questionnaire on learning devices with the M-APOS approach assisted by mind mapping can be seen in Table 1. 
TABLE 1. RESUlTS OF QUESTIONNAIRE TEACHER RESPONSE TO RPP AND LKPD BASED ON M-APOS APPROACH ASSISTED BY MIND MAPPING

\begin{tabular}{|c|c|c|c|c|}
\hline No. & Aspects Rated & Average & Percentage & Categories \\
\hline 1. & Attraction & 3,75 & 94 & Very Practical \\
\hline 2. & Process of Use & 4 & 100 & Practical \\
\hline 3. & Ease of Use & 3,5 & 88 & Very Practical \\
\hline 4. & Time & 3,17 & 79 & Practical \\
\hline 5. & Equivalence & 3,67 & 92 & Very Practical \\
\hline \multicolumn{2}{|c|}{ Average Overall } & 3,62 & 91 & Very Practical \\
\hline
\end{tabular}

The results of the questionnaire response of the learner also showed that LKPD based M-APOS assisted mind mapping developed already have high practicality. This can be seen from the value obtained from the student questionnaire calculation which is worth 3.52 with a percentage value of $88 \%$ which also includes a high practicality category. In detail can be seen the value of practicality based on questionnaire learners in Table 2 .

TABLE II. REsults of StUdENT Response of StUdENT RESPONSE TO LKPD BASED ON M-APOS APPROACH WITH MIND MAPPING ASSISTANCE

\begin{tabular}{|c|c|c|c|c|}
\hline No. & Aspects Rated & Average & Percentage & Categories \\
\hline 1. & Ease of Use & 3,51 & 88 & Very Practical \\
\hline 2. & Timing Efficiency & 3,23 & 81 & Practical \\
\hline 3. & Benefits of LKPD & 3,67 & 92 & Very Practical \\
\hline \multicolumn{2}{|c|}{ Average Overall } & 3,52 & 88 & Very Practical \\
\hline
\end{tabular}

After completing the learning activities, learners are asked to give their message and their impression during learning with LKPD based on M-APOS approach with mind mapping. The thing that can be revealed from the students' answers is that students enjoy learning with the developed LKPD. Cover from LKPD make learners interested to learn math, color LKPD favored by learners, language very communicative in accordance with level of development learners make learners easy to understand intention and purpose of problem exist in LKPD. Structured activities make students understand what needs to be done, even though they generally recognize that learning to use MAPOS-based LKPD with mind mapping assistance is very different from the learning they have received so far. Initially the students did look confused when answering the questions that were in the LKPD, but after several meetings students were very happy to learn mathematics using the developed LKPD. Students who are considered the laziest, like to hold friends and often come out while studying mathematics by their friends, while studying with LKPD based on the M-APOS approach assisted by mind mapping, they are very enthusiastic about learning. He said he understood the concepts learned and felt challenged to solve the problems given because the problems given were found in their daily lives. Learners admit dislikes if the teacher gives the subject matter by lecturing long in front, bored and do not understand what is given for not trying to solve the problem itself.

During the learning process learners are very eager to complete their LKPD each, some even race speed, neatness, and so on. Mind mapping is something new for learners in SMPN 1 Kec.Kapur IX, making mind mapping makes them become more enthusiasm because they can expel their artistic talent while memorizing the concept that has been studied so far. Learners acknowledge by mind mapping they become more familiar with the concepts learned, their memories are more lasting, they better know the relationship between the concepts they have learned and facilitate them in making the conclusions of learning and in describing mind mapping each activity which is very fun because learning math is perceived as learning art subjects only, they look lebh relaxed, relaxed and happy. In conclusion the students who were initially afraid, bored and disliked with mathematics by learning using a device based on the MAPOS approach assisted by mind mapping made mathematics favored by students, and even became the anticipated learning by students, students felt disadvantaged if they did not learn mathematics and learning time feels shorter than usual by students.

Based on the result of teacher's and learner's response, it is found that learning tools with M-APOS approach using mind mapping are practically used and can increase the learning activity and motivation of learners and can increase the communication ability of students well. This is in accordance with the sense of practicality contained in the KBBI, which is practical and easy to use. In addition, the learning activities carried out can attract students' interest to learn, so as to create active, creative, effective, challenging, happy and weighted learning and to establish communication between students and teachers, students with other students and students with material teaching that is used either communication in everyday language or in mathematical language.

In addition to the questionnaire response of teachers and learners above, the practicality of learning tools developed can also be seen from the observations during the learning process takes place. The value obtained from the calculation of the observation data is 3.44 where the practicality of the learning device reaches $86 \%$. This means that the learning device based on the M-APOS approach with mind mapping is very practical to use in classroom learning. Observation result of learning device implementation can be seen in Table 3.

TABLE III. RESUlt OF OBSERVATION OBSERVATION OF LEARNING DEVICE BASED ON M-APOS-BASEd Mind MAPPING APPROACH

\begin{tabular}{|c|l|c|c|c|}
\hline No. & \multicolumn{1}{|c|}{ Aspects Rated } & Average & Percentage & Kategori \\
\hline 1. & Kegiatan Pendahuluan & 3,67 & 92 & Very Practical \\
\hline 2. & Kegiatan Inti & 3,29 & 82 & Practical \\
\hline 3. & Kegiatan Penutup & 3,38 & 84 & Very Practical \\
\hline \multicolumn{2}{|c|}{ Average Overall } & 3,44 & 86 & Very Practical \\
\hline
\end{tabular}

During conducting observations of learning devices, researchers see changes from each meeting. Learners who initially look lazy, often out of class and do not make the task, become more diligent and comfortable to follow the learning of mathematics. Teachers who usually have difficulty controlling classes during learning become easier to control students. Students look cool and enthusiastic to work on the LKPD distributed by the teacher, even though the class is a bit noisy, but it is because they are discussing each other to answer the LKPD distributed. Learners compete with each other, the atmosphere of discussion looks very active. The language used by students to discuss is still 
dominated by regional languages. Researchers see the motivation of students in general is high to learn mathematics than those who previously admitted they were afraid and lazy to learn mathematics.

\section{CONCLUSION}

Based on the results of the data analysis and the results of the learning tools developed in the field, it can be concluded that this development research has produced a practical learning tool with the M-APOS approach with mind mapping that is practical to be used in teaching materials in class VII SMP / MTs second semester. The resulting LKPD facilitates learners to make them easy to learn. In addition, using learning tools based on M-APOS approach with the help of mind mapping makes learning mathematics fun for learners and can be used as indicators to improve students' mathematical communication skills and learning outcomes.

Based on research that researchers have done, the researchers suggest for teachers and learners who use this learning tool is expected to improve the ability of mathematical communications owned. For the next researcher, the researcher suggested to develop the learning device for other materials and the implementation of the experiment is extended to several other schools.

\section{REFERENCES}

[1] Sumarmo. U., Hendriana. H, Penilaian pembelajaran matematika. Bandung: Refika Aditama, 2014.

[2] Martin. M. O., Mullis. I. V., Foy. P., \& Stanco. G. M, TIMSS 2015 international result in mathematics, Chestnut Hill: TIMSS \& PIRLS International Study Center, 2015.

[3] Tim Pusat Penelitian Pendidikan Badan Penelitian dn Pengembangan Kementrian Pendidikan dan Kebudayaan. Kemampuan matematika siswa SMP Indonesia menurut Benchmark International TIMSS 2011.

http://litbang.kemdikbud.go.id/data/puspendik/HASIL $\% 20$ RISET/TIMSS/LAPORAN\%20TIMSS\%202011\% $20-$

20Kemampuan\%20Matematika\%20Siswa\%20SMP\%2 0Indonesia\%20berdasarkan\%20Benchmark\%20TIMSS \%202011.pdf [Accessed 13 April 2018]

[4] Rusyda. N. A, "A cognitive Analysis of Students" Mathematical Problem Solving Ability on Geometry", Journal of Physics: Confrence Series 895, 2015.

[5] Sumartini. T. S, "Peningkatan kemampuan pemecahan masalah matematis siswa melalui pembelajaran berbasis masalah", Jurnal Musharafa, vol. 8, pp. 11-21, 2016.

[6] Anisa. W. N, "Peningkatan kemampuan pemecahan masalah dan komunikasi matematik melalui pembelajaran pendidikan matematika realistik untuk siswa SMP Negeri di Kabupaten Garut", Jurnal Pendidikan dan Keguruan 1, vol. 1, 2014

[7] Jensen. E, Brain based learning, Yogyakarta: Pustaka Pelajar, 2008.

[8] Sapa at. A, Brain based learning. (Online) Diakses dari : http://matematika.upi.edu/index.php/brain-basedlearning/. [Accessed 13 April 2017], 2009.

[9] Hake. R.R, Analizing Change / Gain Scores. [Online]. Available: http: // www.physics.indiana.edu/sdi/AnalyzingChange-Gain.pdf. [Accessed 13 April 2017], 1999.

[10] Jensen. E, Pemelajaran berbasis-otak, Jakarta: Indeks, 2011.
[11] Duman. B, "The effect of brain-based instruction to improve on students' academic achievement in social studies instruction", 9th International Conference on Engineering Education, vol. 24, pp. 17-25, 2006.

[12] Caine. R. N., \& Caine. G, "Understanding a brain-based approach to learning and teaching", Educational Leadership, vol. 48, pp. 43-47, 1990. 